\title{
COMPARISON OF SERUM TOTAL PROTEIN AND SERUM ALBUMIN AFTER INFUSION OF AMINO ACID OF THE 15\%-30\% BURN PATIENTS
}

\author{
N Kamrun', Zeba-Un-Naher ${ }^{2}$, M Ali ${ }^{3}$, Bashar T ${ }^{4}$, MI Arslan ${ }^{5}$
}

\begin{abstract}
The aim of the study to find out the ratio of raise of serum total protein and serum albumin during amino acid supplementation in burn patients.

This interventional study cross sectional study was done in the Department of Biochemistry, Bangabandhu Sheikh Mujib Medical University (BSMMU), Dhaka, Bangladesh during January 2008 to December 2008. A total of 40 acute burn injury (within 24 hours of burn) patients of 20-45 years age with 15\%-30\% burn were selected for this study as case. The study subjects were divided into two groups: Group I represent superficial burn \& Group II represents deep burn. In group-I, serum albumin was decreased by $19.24 \%$ after infusion and in group-II, that was decreased by $22.45 \%(\mathrm{p}<0.05)$. Serum total protein significantly increased after infusion of amino acid but serum albumin significantly decreased after infusion of amino acid.
\end{abstract}

Key word: Serum total protein, serum albumin, infusion of amino acid.

\section{INTRODUCTION}

In Bangladesh the prevalence burn injury is very high though exact statistics is not available. A burn is an injury caused by heat, cold, electricity, chemicals, light, radiation, or friction. Burn is one of the top five causes of fatal injuries to people ${ }^{1}$. Chemical burns like throwing acids by culprits are common in Bangladesh $^{2}$. Burn cause not only physical injury but psychological abnormality. Symptoms of depression are highly prevalence in burn reconstruction patients ${ }^{3}$.

Defects of both cellular and humoral immune function increase the likelihood of infection ${ }^{4}$. A welldescribed array of metabolic derangements occurs after burn. Metabolic response to stress could lead to malnutrition, which will worsen the stress situation by increasing the patient's susceptibility to infection ${ }^{5}$. Infection is the most common cause of death in hospitalized burn patients. This is associated with a variety of documented immunologic abnormalities. Many immunologic functions are dependent upon optimal availability of specific amino acids, and that routine diets do not provide sufficient protein to satisfy the needs of seriously burned individuals ${ }^{6}$. Adequate nutritional support may prevent weight loss following severe burn injury. However, persistently low levels of serum albumin, transferring and serum total protein in burn patients have suggested that a protein deficiency may continue to exist which is out of proportion to energy requirements.

Burns and sepsis have in common a rapid net catabolism of body protein, as well as a redistribution of the nitrogen pool within the body. Provision of dietary protein and/or amino acids is essential for maintaining

${ }^{1}$ Consultant, Biochemistry, Department of Burn Unit, Dhaka Medical College, Dhaka.

${ }^{2}$ Medical Officer, Department of Biochemistry, BSMMU, Dhaka.

${ }^{3}$ Medical Officer, Department of Ophthalmology, BSMMU, Dhaka.

${ }^{4}$ Research Assistant, Department of Pharmacology, BSMMU, Dhaka.

${ }^{5}$ Professor \& Chairman, Department of Biochemistry, BSMMU, Dhaka. Bangladesh 
net protein catabolism. Furthermore, it seems likely that a higher-than-normal intake of protein may be useful. Even the mild stress of simple bed rest increases the protein requirement to maintain nitrogen balance. Branched chain amino acids (BCAAs) possess regulatory properties on protein metabolism. Prospective controlled trials of BCAA supplementation in septic patients demonstrated an improvement in patients' nutritional status and outcome. A catabolic insult like burn induces a marked generalized net protein catabolism in the muscle. This accelerated protein breakdown is associated with inhibited uptake of amino acids (AAs) by the muscles, leading to an increased flux of amino acids from the periphery to the liver ${ }^{5}$. Supplementation with glutamine dipeptide was associated with enhanced glutamine plasma concentrations, decreased gut permeability and endotoxin levels as well as wound healing time and lower cost of hospitalization ${ }^{7}$.

Alexander et al $(1980)^{6}$ showed that serum total protein was significantly higher $(\mathrm{p}<0.0002)$ in children who took higher high protein diet. Though the serum albumin was higher in high protein diet group, it did not reach the significant level. EI-Gallal and Yousef $(2002)^{8}$ found that the mean value of total protein of patients supplemented with parenteral amino acids remained at nearly normal level $(6.21 \mathrm{gm} / \mathrm{dl})$ compared with that of patients without parenteral amino acids supplement (only enteral nutrition), the difference was statistically significant $(\mathrm{p}<0.05)$. The authors showed that parenteral supplementation with enteral nutrition is safe, gives better results in minimizing the negative nitrogen balance and to a great extent preserves the nutritional integrity of severely burned patients ${ }^{8}$. This interventional study on amino acid supplementation in burn patient was carried out to find out to compare between total protein and albumin in burn and deep burn before and after infusion of amino acid.

\section{SUBJECTS AND METHODS}

This interventional study on amino acid supplementation in burn patient was carried out in the Department of Clinical Pathology, Internal Medicine (Unit-III), Outpatient Department of Department of Biochemistry, Bangabandhu Sheikh Mujib Medical University (BSMMU), Dhaka, Bangladesh, during the period from January 2008 to December 2008. This study included burn patient of 20-45 years of age, both sexes and patients with burn of $15-30 \%$ body surface area in the above mentioned hospital during the study period. Burn patients with other co-morbid conditions such as diabetes mellitus, hypertension, renal impairment, hepatic diseases or malnutrition were excluded from the study.

An informed written consent was taken from all the study subjects to participate into the study. After admission of patients with acute burn injury, they were advised to take same quality of oral diet during the study period. Then blood sample for serum total protein and albumin will be taken on $1^{\text {st }}$ and $2^{\text {nd }}$ day of admission. Then they were infused $500 \mathrm{ml}$ of amino acid (prosol i.v.) on $2^{\text {nd }}$ day to $6^{\text {th }}$ day of burn. Blood sample for total protein and albumin were further taken 48 hours after last infusion of amino acid ( $8^{\text {th }}$ day of burn). Blood was transferred immediately into a dry, clean plastic test tube with a gentle push to avoid hemolysis. Collected blood was allowed to clot \& then centrifuged. Separated serum was collected into plastic micro centrifuged tube \& appropriately labeled which was used for estimation of total protein and albumin. All the values were recorded in a data collection sheet (questionnaire). Statistical Analysis: Continuous data were expressed as mean \pm SD. Statistical analysis were performed by using "Statistical Package for Social Sciences (SPSS)," for window version-16.0. Data were analyzed by

paired t-test, unpaired t-test, proportion test and Chi square test using Statistical Package for Social Sciences (SPSS) window version. 


\section{OBSERVATIONS AND RESULTS}

The mean age was $28.35 \pm 6.81$ years in group I and that of Group-II was $30.85 \pm 7.32$ years. No significant difference $(\mathrm{p}>0.05)$ was found between two group regarding mean age distribution. Male patient was $40.0 \%$ in Group-I and 40.0\% in Group-II. Male female ratio was 2:3.

The mean serum total protein of the study subjects before infusion of amino acid was $53.66 \pm 3.39 \mathrm{~g} / \mathrm{L}$ and after infusion was $64.94 \pm 3.85 \mathrm{~g} / \mathrm{L}$. The mean serum albumin of the study subjects before infusion was $26.59 \pm 2.61 \mathrm{~g} / \mathrm{L}$ and after infusion was $21.06 \pm 3.39 \mathrm{~g} / \mathrm{L}$. The mean difference of serum total protein and serum albumin were significant $(\mathrm{p}<0.001)$ (Table I).

Table I: Comparison of serum total protein and serum albumin before and after infusion of amino acid of the study subjects.

\begin{tabular}{lcccc}
\hline \multicolumn{1}{c}{ No. of study subjects } & $\begin{array}{c}\text { Before infusion } \\
(\mathbf{n}=\mathbf{4 0}) \\
(\mathbf{M e a n} \pm \mathbf{S D})\end{array}$ & $\begin{array}{c}\text { After infusion } \\
(\mathbf{n = 4 0 )} \\
(\mathbf{M e a n} \pm \mathbf{S D})\end{array}$ & t value & p value \\
\hline Total protein (g/L) & $53.66 \pm 3.39$ & $64.94 \pm 3.85$ & -22.57 & $<0.001^{*}$ \\
Serum albumin (g/L) & $26.59 \pm 2.61$ & $21.06 \pm 3.39$ & 13.39 & $<0.001^{*}$ \\
\hline
\end{tabular}

Unpaired t test was done as test of significant.

* Significant

The percentage change of serum total protein concentration before and after infusion of amino acid between two groups were increased by $22.98 \%$ and $18.94 \%$ increased after infusion in group I and group II respectively. Similarly, the percentage change of serum albumin concentration before and after infusion of amino acid between two groups was decreased by $19.24 \%$ in group I and $22.45 \%$ in group II after infusion. There were significant difference $(\mathrm{p}<0.05)$ between two groups (Table IV).

Table IV: Change of total protein concentration and serum albumin (in percentage) before and after infusion of amino acid between two groups of study subjects.

\begin{tabular}{lcccc}
\hline $\begin{array}{l}\text { Change of total protein } \\
\text { concentration }\end{array}$ & $\begin{array}{c}\text { Group-I } \\
\text { Superficial burn } \\
(\mathbf{n}=\mathbf{2 0})\end{array}$ & $\begin{array}{c}\text { Group-II } \\
\text { Deep burn } \\
(\mathbf{n = 2 0})\end{array}$ & z- value & p value \\
\hline $\begin{array}{l}\text { Increase of serum total } \\
\text { protein (g/L) }\end{array}$ & $22.98 \%$ & $18.94 \%$ & 3.13 & $<0.001^{*}$ \\
$\begin{array}{l}\text { Decrease of Serum albumin } \\
\text { (g/L) }\end{array}$ & $19.24 \%$ & $22.45 \%$ & 2.51 & $<0.005^{*}$ \\
\hline
\end{tabular}

Proportion test (z test) was done as test of significant.

* Significant.

\section{DISCUSSION}

This interventional study on amino acid supplementation in burn patient was carried out to evaluate whether amino acid infusion in the study subjects increases serum total protein and serum albumin or not. The mean age was $28.35 \pm 6.81$ years and $30.85 \pm 7.32$ years in group I and group II respectively, with range from 20 to 45 years. The mean age was almost similar between two groups. Male patient was $40.0 \%$ in Group-I and 40.0\% in Group-II. Male female ratio was 2:3. 
Serum total protein and serum albumin were measured before and after infusion of amino acid in each study subjects. Serum total protein was significantly $(p<0.001)$ increased after infusion ${ }^{4,5,6,8,9}$.

This study well agreed with EI-Gallal and Yousef $(2002)^{8}$ where they showed the mean value of total protein of patients supplemented with parenteral amino acids remained at nearly normal level (6.21 $\mathrm{gm} / \mathrm{dl}$ ) compared with that of patients without parenteral amino acids supplement (only internal nutrition). Finally they showed that parenteral supplementation with internal nutrition is safe, gives better results in minimizing the negative nitrogen balance and to a great extent preserves the nutritional integrity of severely burned patients. Trop (2008) ${ }^{10}$ stated that soon after a burn, changes are observed in the concentration of the plasma proteins. These protein changes affect plasma's colloid osmotic pressure, which depends on both the concentration and the molecular size of the constituent protein molecules. The decrease in albumin concentration develops and remains, owing to an increased rate of catabolism, losses of exudates from the burn wound, and failure of anabolism to compensate for those losses. This study also revealed statistical significant ( $p>0.001$ ) decreased level of serum albumin concentration. From the day of admission till 48 hours after last infusion. But this findings different from the study done abroad who found inverse relation. This inconsistent findings may be due to failure of supplying adequate amino acid infusion actually required for the study subjects, Dietary factors might be a one of the important factors for this inconsistent findings because this study could not ascertain the adequate amount of diet for the study subjects. Ijichi et al. (2003) ${ }^{11}$ stated that increase level of serum albumin in adult depends majority on oral diet but as we are developing country \& most of the people are in below the average daily caloric intake, the findings could be the real picture for the country as well. It can be predicted that if dietary requirements for the burn subjects can be provided along with a. a. infusion we could find similar findings regarding serum albumin with other findings.

Moreover, the treatment protocol which used to apply on the studies differs from treatment protocol on our study. The basic aim of their treatment protocol is to halt or delay the catabolic state in the burn subjects, but unfortunately our protocol findings regarding serum albumin.

In conclusion, treatment protocol along with amino acids infusion \& caloric requirements through the diet should be re-evaluated in context to our country so that we can reduce post burn morbidity and mortality.

\section{REFERENCES}

1. Lal P, Rahi M, Jain T and Ingle GK. Epidemiological Study of Burn injuries in a slum Community of Delhi. Indian Journal of Community Medicine 2006; 31(2): 201-203.

2. Rahman MS and Shakoor MA. Concepts in rehabilitation of burn patients. 2007; 25: 139-143.

3. Thombs BD, Haines JM, Bresnick MG, Russel GM, Fauerbach JA and Robert J. Depression in burn reconstruction patients: symptoms prevalence and association with body image and physical function. Gen Hosp Psychiatry 2008; 29(1): 14-20.

4. Hart DW, Wolf SE, Herndon DN, Chinkes DL, Lal SO, Obeng MK et al. Energy expenditure and caloric balance after burn increased feeding leads to fat rather than lean mass accretion. Annals of surgery 2002; 235(1): 152-161. 
5. Bandt JP and Cynober L. Therapeutic Use of Branched-Chain Amino Acids in Burn, Trauma, and Sepsis. 2006; 136: 308-313.

6. Alexander JW, mac Millan BG, Stinnett JD, Ogle CK, Bozian RC, Fischer JE et al. Beneficial effects of aggressive protein feeding in severely burned children. 1980; 192(4): 505-516.

7. Zhou YP, Jiang ZM, Sun YH, He GH and Shu H. The effects of supplemental glutamine dipeptide on gut integrity and clinical outcome after major esharectomy in severe burns: a randomized, double-blind, controlled clinical trial. Science Direct-Clinical Nutrition Supplement 2004.

8. El-Gallal ARS and Yousef SM. Our experience in the nutritional support of burn patients. 2008; 15: 79.

9. Atiyeh BS, Gunn SW, Dibo SA, 2008. Metabolic implications of severe burn injuries and Their management: A systematic review of the literature. World J Surg Vol. 32, pp. 1857-1869.

10. Trop M, Schintler M, Spendel S and Stockenhuber A. Unhealed wounds, hypoalbuminaemia and cachexia in a burned child-where is the limit? Annals of Burns and Fire Disasters 2008; 21: 59-94.

11. Ijichi C, Matsumura T, Tsuji T and Eto Y. Branched-chain amino acids promote albumin synthesis in rat primary hep0atocytes through the mTOR signal transduction system. Biochemical and Biophysical Research Communications 2003; 303: 59-64. 